\title{
Histopathological changes induced by Hysterothylacium deardorffoverstreetorum larvae (Nematoda: Raphidascarididae) in Priacantbus arenatus Cuvier, 1829 (Actinopterygii)
}

\author{
Alteraçóes histopatológicas induzidas por larvas de Hysterothylacium deardorffoverstreetorum
} (Nematoda: Raphidascarididae) em Priacanthus arenatus Cuvier, 1829 (Actinopterygii)

Bianca Porto Kuraiem ${ }^{1}$; Marcelo Knoff; ${ }^{*}$ Nilza Nunes Felizardo'; Rodrigo Caldas Menezes ${ }^{3}$; Delir Corrêa Gomes²; Sérgio Carmona de São Clemente ${ }^{1}$

\author{
${ }^{1}$ Laboratório de Inspeção e Tecnologia de Pescado, Faculdade de Medicina Veterinária, Universidade Federal Fluminense - UFF, \\ Niterói, RJ, Brasil \\ ${ }^{2}$ Laboratório de Helmintos Parasitos de Vertebrados, Instituto Oswaldo Cruz, Fundação Oswaldo Cruz - FIOCRUZ, Rio de Janeiro, \\ RJ, Brasil \\ ${ }^{3}$ Laboratório de Pesquisa Clínica em Dermatozoonoses em Animais Domésticos, Instituto Nacional de Infectologia Evandro Chagas, \\ Fundação Oswaldo Cruz - FIOCRUZ, Rio de Janeiro, RJ, Brasil
}

Received November 22, 2016

Accepted March 7, 2017

\begin{abstract}
Priacanthus arenatus is a fish that occurs in the waters of the western Atlantic Ocean and has few records of parasitism. This study aimed to report histological changes caused by the larvae of Hysterothylacium deardorffoverstreetorum. Between July and December, 2013, 30 samples of P. arenatus were obtained from fish markets in the cities of Niterói and Rio de Janeiro, state of Rio de Janeiro, Brazil. Fragments of spleen, liver, stomach wall and mesentery tissues containing nodules and free parasites were extracted to histopathological study. Through histological analysis it was verified that these nodules consisted of connective tissue capsules, in which the parasites were located, with granulomatous inflammation mainly comprised of macrophages and lymphocytes. These nodules also consisted of a central portion of acellular amorphous material, formed by concentric layers, which was slightly basophilic and contained tunnels and, sometimes, parasite debris. The presence of tunnels in acellular amorphous material suggests that the larvae are initially located at the center of the nodules and then they migrate to the surface.
\end{abstract}

Keywords: Hysterothylacium deardorffoverstreetorum, histopathology, Priacanthus arenatus, atlantic bigeye.

\section{Resumo}

Priacanthus arenatus é um peixe que ocorre nas águas do Atlântico ocidental com poucos relatos de parasitimo. Este estudo objetivou relatar as características histológicas causadas pelas larvas de $H$. deardorffoverstreetorum em $P$. arenatus. Entre julho e dezembro de 2013, 30 espécimes de P. arenatus foram obtidas de mercados de peixes das cidades de Niterói e Rio de Janeiro, Estado do Rio de Janeiro, Brasil. Fragmentos de baço, fígado, parede do estômago e mesentério contendo nódulos foram extraídos para estudo histopatológico. Foi observado através de análise histológica que esses nódulos eram constituídos por uma cápsula de tecido conjuntivo, onde se localizavam os parasitas viáveis, com infiltrado inflamatório granulomatoso, constituído, predominantemente, por macrófagos e linfócitos e por porçáo central de material amorfo acelular, formado por lâminas concêntricas, ligeiramente basofílico, contendo túneis e, por vezes, restos parasitários. A presença de túneis no material amorfo acelular dos nódulos analisados histologicamente sugerem que as larvas se localizam inicialmente no centro do granuloma e depois migram para a superfície do mesmo.

Palavras-chave: Hysterothylacium deardorffoverstreetorum, histopatologia, Priacanthus arenatus, olho-de-cão.

\footnotetext{
*Corresponding author: Marcelo Knoff. Laboratório de Helmintos

Parasitos de Vertebrados, Instituto Oswaldo Cruz, Fundação Oswaldo Cruz

- FIOCRUZ, Avenida Brasil, 4365, Manguinhos, CEP 21040-900, Rio de

Janeiro, RJ, Brasil. e-mail: knoffm@ioc.fiocruz.br
} 


\section{Introduction}

Priacanthus arenatus Cuvier, 1829, the Atlantic bigeye, is a fish of appreciated flavor and high commercial value that occurs in the waters of the western Atlantic Ocean. This fish has nocturnal habits, lives between the coastline and a water depth of around 130 meters and feeds on small fish, crustaceans, and polychaetes (FIGUEIREDO \& MENEZES, 1980).

Among the parasites that present risks to human health and can be found in this fish species, nematodes of the families Anisakidae and Raphidascarididae can be highlighted. These nematodes use teleost fish, cephalopod molluscs and small crustaceans as intermediate hosts (ADAMS et al., 1997).

There are few records of parasitism by helminths in P. arenatus. Pinto et al. (1988) reported the presence of Oncophora melanocephala Baudin-Laurencin, 1971; Fábio (2000) recorded the presence of O. melanocephala, Stephanostomum seriolae Yamaguti, 1970, Pseudopecoelus priacanthi (MacCallum, 1921), Brachyphallus parvus (Manter, 1947) and Diplectanotrema balistes Price, 1937. Tavares et al. (2001) investigated the ecology of the metazoan parasite community of this fish and registered the presence of Lecithochirium sp., Opecoeloides sp., Diplectanotrema sp., Scolex pleuronectis, Polymorphus sp., O. melanocephala, Raphidascaris sp., Pseudoterranova sp. and Contracaecum sp.

Humans become accidental hosts by ingesting larvae of this nematode, through consumption of raw or undercooked fish, or fish that has been smoked or salted improperly. They can develop anisakidosis, which is a disease caused by ingestion of infective larvae of nematodes belonging to the family Anisakidae (ADAMS et al., 1997; KLIMPEL \& PALM, 2011).

Overstreet \& Meyer (1981) recorded the presence of hemorrhagic lesions in the stomach of primates inoculated with Hysterothylacium sp. larvae and suggested that species belonging to this genus may present potential zoonotic risk. Subsequently, Yagi et al. (1996) reported a case of human infection through eating fish infested by Hysterothylacium aduncum (Rudolphi, 1802).

Felizardo et al. (2009) reported that larvae of Hysterothylacium sp. were present in Paralichthys isosceles Jordan, 1890, in relation to granuloma formation in various organs. Subsequently, these larvae were characterized genetically and morphologically as Hysterothylacium deardorffoverstreetorum Knoff, Felizardo, Iñiguez, Maldonado Jr, Torres, Pinto and Gomes, 2012 (KNOFF et al., 2012). Fontenelle et al. (2013) also recorded the presence of these larvae in Cynoscion guatucupa (Cuvier, 1830), caught on the coast of the state of Rio de Janeiro.

The current study reports the pathological changes caused by the $H$. deardorffoverstreetorum larvae in $P$. arenatus that were previously identified by Kuraiem et al. (2016).

\section{Materials and Methods}

Between July and December, 2013, 30 samples of $P$. arenatus with 20-63 $($ mean $=38.3) \mathrm{cm}$ of length and with 400-3,600 (mean $=1,210) \mathrm{g}$ of weight were obtained from fish markets in the cities of Niterói and Rio de Janeiro, state of Rio de Janeiro, Brazil.
The fish were transported in cool boxes containing ice to the Fish Inspection and Technology Laboratory of the Fluminense Federal University, where they were necropsied. The nematode larvae that were collected were fixed, clarified and preserved as described by Knoff \& Gomes (2012). The morphological analysis to identify $H$. deardorffoverstreetorum larvae was performed by Kuraiem et al. (2016).

Small fragments of spleen, stomach, liver and mesentery tissues containing nodules and free parasites were extracted, fixed in 10\% formaldehyde and processed for paraffin embedding (BEHMER et al., 1976). Histological sections of $5 \mu \mathrm{m}$ of thickness were mounted on microscope slides and stained with hematoxylin-eosin (HE) for subsequent analysis. Photomicrographs were obtained using a Leica DM1000 microscope coupled to a Leica DFC420 digital camera.

One slide showing a histopathological section through one of the parasites at the infection site was deposited in the Helminthological Collection of the Oswaldo Cruz Institute, Rio de Janeiro, RJ, Brazil, under the number 38207.

\section{Results and Discussion}

Among the 30 fish obtained, 20 (66.7\%) were infected by a total of 1,994 third-instar $\left(\mathrm{L}_{3}\right)$ larvae of $H$. deardorffoverstreetorum: 237 larvae were in a free form and 1,757 were inside granulomas.

Nodules containing at least one of these $\mathrm{L}_{3}$ were present in all the infected fish. Macroscopically, they were pale brown circumscribed nodules with a friable consistency and surrounded by a capsule. These nodules measured $0.2-1.2 \mathrm{~cm}$ in diameter. They were present in the mesentery; on the surface and in the parenchyma of the liver and spleen; in the stomach lining, in the intestinal serous membrane; and in the abdominal muscles. The larvae were located on the surface of these nodules and sometimes it was possible to macroscopically observe some larvae leaving the nodules.

Through histological analysis it was observed that these nodules consisted of connective tissue capsules, in which the parasites were located, with granulomatous inflammatory infiltrate mainly comprised of macrophages and lymphocytes (Figures 1a, 2). Microscopically, these nodules also consisted of a central portion of acellular amorphous material, formed by concentric layers, which was slightly basophilic and contained tunnels and, sometimes, parasite debris (Figure 1a). Figure $1 \mathrm{~b}$ shows a detail from a cross-section through the middle of the esophagus, with the characteristic lateral alae with wedge-shaped support, devoid of basal extension, of $H$. deardorffoverstreetorum third-stage larvae.

In the areas of the organs surrounding these histological alterations, no abnormalities were observed, except in the mesentery, where there was inflammatory infiltrate similar to what was found in their capsules.

Felizardo et al. (2009) described parasitism in P. isosceles caused by $H$. deardorffoverstreetorum larvae that were either free or inserted into the spleen, liver, intestine, mesentery, ovaries, stomach wall, heart serosa, kidneys and abdominal musculature. On the other hand, in the present study, the infection sites were restricted to the spleen, gastric serosa, intestinal serosa, liver, mesentery and abdominal musculature. However, those authors observed the presence of nodular lesions restricted to the stomach mucosa and 

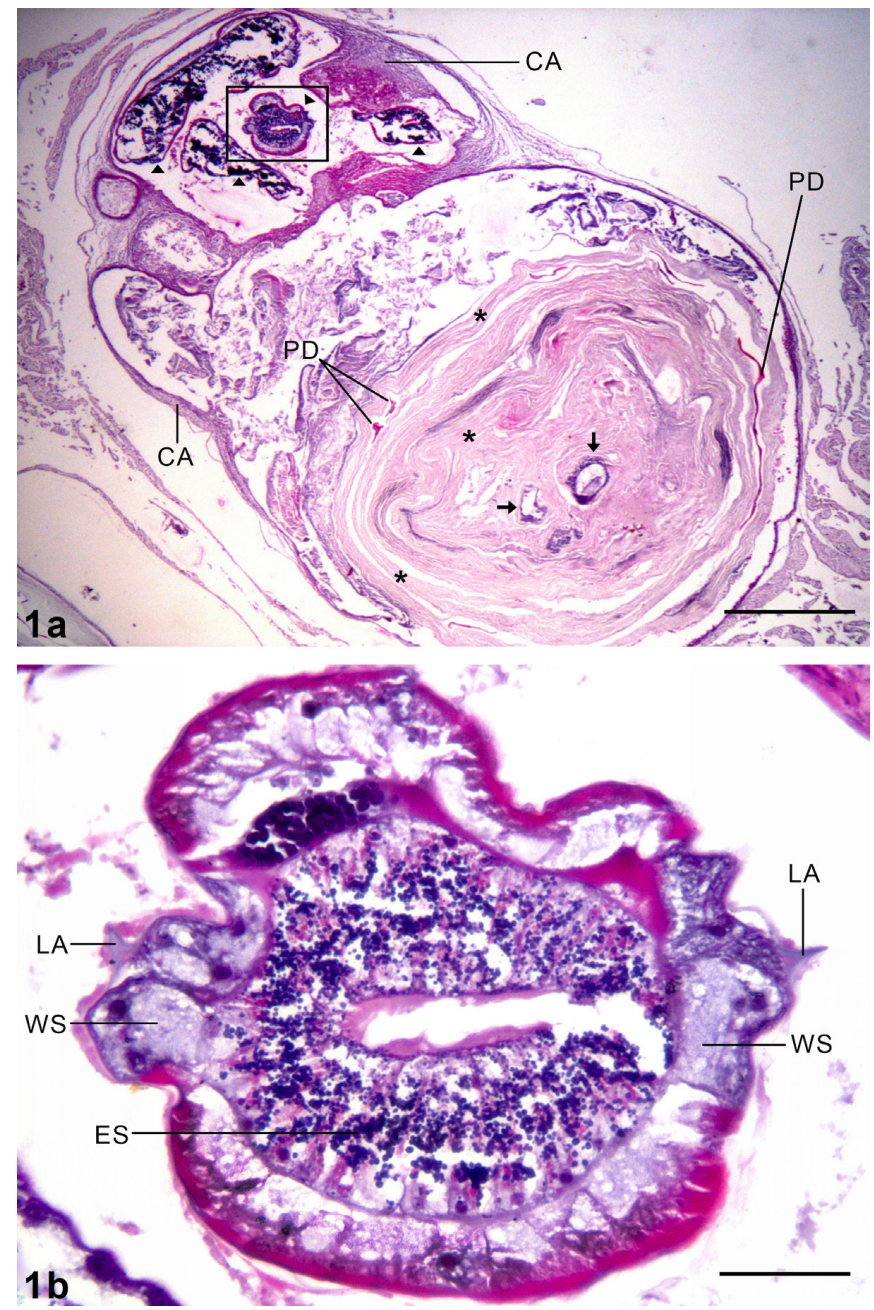

Figure 1. Histological cross-section of the mesentery of Priacanthus arenatus parasitized with third-stage larvae of Hysterothylacium deardorffoverstreetorum. 1a Histological alteration presenting connective tissue capsule with granulomatous inflammation (CA) and larvae of H. deardorffoverstreetorum (arrowheads). The acellular amorphous material in the central portion of the histological alteration was seen to be composed of concentric layers $\left({ }^{*}\right)$, containing tunnels (arrows) and parasite debris (PD). The rectangle indicates the region from which figure $\mathbf{1} \mathbf{b}$ was obtained. $\mathbf{1 b}$ detail from cross-section of the middle of esophagus (ES) and lateral alae (LA), with a wedge-shaped support (WS) for $H$. deardorffoverstreetorum larva. Bars: $1 \mathrm{a}=500 \mu \mathrm{m}$, $1 \mathrm{~b}=50 \mu \mathrm{m}$.

intestinal serosa, which were identified as granulomas through histological examination, while in this study the infection sites of nodular lesions were more varied (mesentery, surface and parenchyma of the spleen and liver, stomach wall, intestinal serosa and abdominal musculature). Moreover, in the present study, it was possible to macroscopically observe larvae inside the capsules of these nodules.

The granulomatous inflammation associated to the larvae of $H$. deardorffoverstreetorum observed in the present study was similar to that described by Felizardo et al. (2009) in the stomach and intestine of the fish Paralichthys isosceles parasitized by larvae of Hysterothylacium.

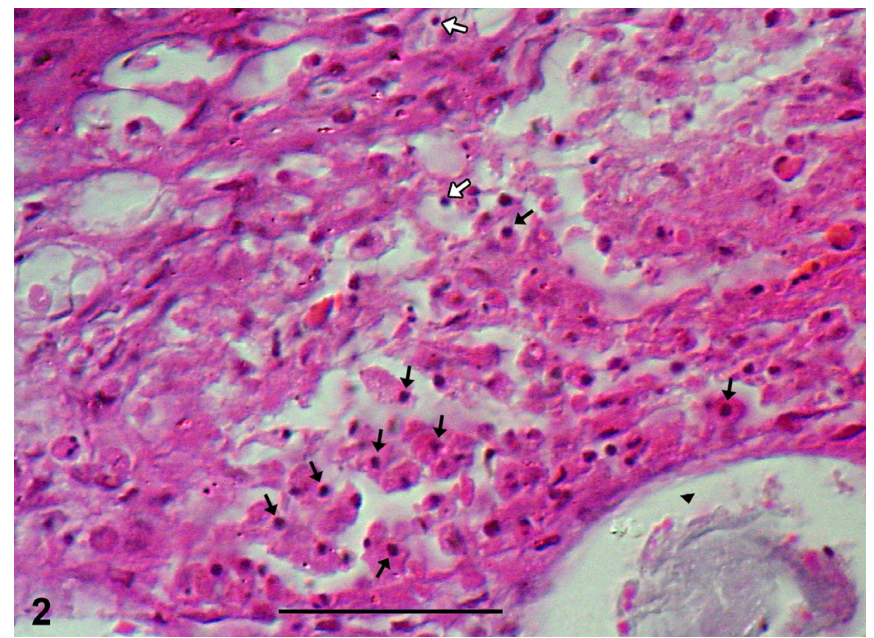

Figure 2. Histological cross-section of the mesentery of Priacanthus arenatus parasitized with third-stage larvae of Hysterothylacium deardorffoverstreetorum. Detail of granulomatous inflammation present in the connective tissue capsule (black arrows indicate some macrophages, white arrows indicate lymphocytes, and arrowhead indicates the parasite larva). Bar: $=60 \mu \mathrm{m}$.

Fontenelle et al. (2013) reported parasitism by $H$. deardorffoverstreetorum in C. guatucupa, in the mesentery, liver serosa and abdominal cavity. However, no formation of granulomas or nodules induced by larvae was observed.

The presence of tunnels in acellular amorphous material in histologically analyzed granulomas suggests that the larvae are initially located at the center of the granuloma and then they migrate to the surface, such as reported by Miyazaki et al. (1988) and Felizardo et al. (2009).

\section{Acknowledgements}

The authors thank Heloisa Nogueira Diniz and Ricardo Baptista Schmidt (Image Production and Processing Service, Oswaldo Cruz, Institute, FIOCRUZ) for processing the figures; and the National Council for Scientific and Technological Development (Conselho Nacional de Desenvolvimento Científico e Tecnológico, CNPq) and the Coordination Office for Improvement of Higher-Education Personnel (Coordenação de Aperfeiçoamento de Pessoal de Nível Superior, CAPES) for partial financial support.

\section{References}

Adams AM, Murrell KD, Cross JH. Parasites of fish and risks to public health. Rev Sci Tech Off Intl Epizoo 1997; 16(2): 652-660. PMid:9501379. http://dx.doi.org/10.20506/rst.16.2.1059.

Behmer OA, Tolosa EMC, Freitas-Neto AG. Manual de técnicas para histologia normal e patológica. São Paulo: EDART; 1976.

Fábio SP. Helminths from Priacanthus arenatus Cuvier, 1829 (Pisces, Priacanthidae) in Cabo Frio, RJ, Brazil. Bol Mus Nac NS. Zool 2000; 421: 1-14. 
Felizardo NN, Menezes RC, Tortelly R, Knoff M, Pinto RM, Gomes DC. Larvae of Hysterothylacium sp. (Nematoda: Anisakidae) in the sole fish Paralichthys isosceles Jordan, 1890 (Pisces: Teleostei) from the littoral of the state of Rio de Janeiro, Brazil. Vet Parasitol 2009; 166(1-2): 175177. PMid:19713041. http://dx.doi.org/10.1016/j.vetpar.2009.08.004.

Figueiredo JL, Menezes NA. Manual de peixes marinhos do Sudeste do Brasil: Teleostei (2). São Paulo: Universidade de São Paulo; 1980. vol. 3.

Fontenelle G, Knoff M, Felizardo NN, Lopes LMS, Clemente SC. Nematodes of zoonotic importance in Cynoscion guatucupa (Pisces) in the state of Rio de Janeiro. Rev Bras Parasitol Vet 2013; 22(2): 281-284. PMid:23778824. http://dx.doi.org/10.1590/S1984-29612013005000019.

Klimpel S, Palm HW. Anisakid nematode (Ascaridoidea) life cycles and distribution: increasing zoonotic potential in the time of climate change? In: Mehlhorn H. Progress in parasitology. Heidelberg: Springer; 2011. p. 201-222.

Knoff M, Felizardo NN, Ińiguez AM, Maldonado A Jr, Torres EJL, Pinto RM, et al. Genetic and morphological characterisation of a new species of the genus Hysterothylacium (Nematoda) from Paralichthys isosceles Jordan, 1890 (Pisces: Teleostei) of the Neotropical region, state of Rio de Janeiro, Brazil. Mem Inst Oswaldo Cruz 2012; 107(2): 186-193. PMid:22415256. http://dx.doi.org/10.1590/S0074-02762012000200006.

Knoff M, Gomes DC. Metodologia básica para coleta e processamento de helmintos parasitos. In: Molinaro EM, Caputo LFG, Amendoeira MRR. Conceitos e métodos para formação de profissionais em laboratórios de saúde. Rio de Janeiro: EPSJV; 2012. vol. 5, p. 251-281.
Kuraiem BP, Knoff M, Felizardo NN, Gomes DC, Clemente SC. Nematode larvae infecting Priacanthus arenatus Cuvier, 1829 (Pisces: Teleostei) in Brazil. An Acad Bras Cienc 2016; 88(2): 857-863. PMid:27254444. http://dx.doi.org/10.1590/0001-3765201620150137.

Miyazaki T, Rogers WA, Semmens KJ. Gastrointestinal histopathology of paddlefish, Polyodon spathula (Walbaum), infected with larval Hysterothylacium dollfusi Schimidt, Leiby \& Kritsky, 1974. J Fish Dis 1988; 11(3): 245-250. http://dx.doi.org/10.1111/j.1365-2761.1988. tb00545.x.

Overstreet RM, Meyer GW. Hemorrhagic lesions in the stomach of Rhesus monkey caused by a piscine ascaridoid nematode. J Parasitol 1981; 67(2): 226-235. PMid:6972442. http://dx.doi.org/10.2307/3280642.

Pinto RM, Vicente JJ, Noronha D, Fábio SP. Redescription of Oncophora melanocephala (Rudolphi, 1819) Baudin-Laurencin, 1971 (Nematoda, Camallanidae). Mem Inst Oswaldo Cruz 1988; 83(2): 233-237. http:// dx.doi.org/10.1590/S0074-02761988000200015.

Tavares LER, Luque JL, Botelho Neto SL. Ecologia da comunidade de metazoários parasitos do olho-de-cão Priacanthus arenatus (Cuvier, 1829) (Osteichthyes, Priacanthidae) do litoral do estado do Rio de Janeiro, Brasil. Rev Bras Zoocienc 2001; 3(1): 45-59.

Yagi K, Nagasawa K, Ishikura H, Nagakawa A, Sato N, Kikuchi K, et al. Female worm Hysterothylacium aduncum excreted from human: a case report. Kisechugaku Zasshi 1996; 45(1): 12-23. 